\title{
Sustainability: The Case Of Siam Cement Group (SCG)
}

\author{
Orose Leelakulthanit, National Institute of Development Administration, Thailand
}

\begin{abstract}
This case discusses the success story of SCG, a long-lasting Thai conglomerate that introduced and implemented the concept of sustainable development. The company has gone through the three stages of sustainable development implementation: the green manufacturing, the greening of the supply chain, and the launching of the eco-value label and eco-value products. As a result, the company has been successful in selling a large number of eco-value products and has been ranked for a long time on the Dow Jones Sustainability Indexes.
\end{abstract}

Keywords: Siam Cement Group; SCG; Sustainability; Sustainable Development

\section{INTRODUCTION}

lobal warming is a gigantic world problem which has gained the attention of various parties, especially the business sector. Good companies can no longer maximize their profit only and leave the quality of life issue in the hands of the government to make use of the tax paid by the companies in raising the level of people's quality of life. The new thinking of the triple bottom lines of the company, which comprise profit, people, and the planet, calls for attention of the companies to go beyond profit and focus also on promoting the happy lives of their employees and the general public, as well as preserving the environment. SCG, which has been doing a good job in promoting the happy working lives of its employees, with its long-held value of the belief in the value of individuals, wants to also create a new agenda of sustainable development that is in line with SCG's value of social responsibility. This case will address the issue of what SCG has done in order to bring about the success of sustainable development implementation.

\section{SCG BACKGROUND}

SCG was established in 1913, following a royal decree of His Majesty King Rama VI to produce cement. Their cement was used as the main building material for infrastructure projects at that time and the company and its projects greatly contributed to the progress of the country. SCG has grown continually since then and has diversified into three core businesses: SCG Cement-Building Materials, SCG Paper, and SCG Chemicals.

SCG's four main business philosophies are: 1) adherence to fairness, 2) dedication to excellence, 3) belief in the value of individuals, and 4) concern for social responsibility, stressing on the importance of sustainable natural resource management and environmental stewardship.

By 2015, SCG wants to be recognized as an innovative workplace and as a role model for corporate governance and sustainable development in the ASEAN region. The company is committed to contributing to sustainable progress and to creating value for its customers, employees, and stakeholders and enhancing quality of life and well-being of people in society. In order to accomplish its goals, a strategy has been adopted by the company with two main aspects: expansion into the ASEAN region and building competitiveness through high value-added products. SCG intends to become a leader among international organizations and to operate with strict adherence to corporate governance principles and high safety standards. According to them, this will ensure excellent operating results, transparency, and fairness; and by operating in accordance with sustainable development principles, they will be able to demonstrate their continued concern for safety, the environment, and the community. 


\section{SCG AS AN INNOVATIVE ORGANIZATION}

In 2005, SCG established a working committee dedicated specifically to innovation. In doing so, it hoped to be able to identify the policies and directions that would assist employees at every level in recognizing the significance of innovation and creating benefit from such innovation. SCG encouraged its staff to become "Inno People." These individuals were to possess the key characteristics of being open-minded, assertive, have the ability to take risks, think outside the box, and be eager to learn. At the same time, managers were encouraged to be "Inno Leaders"; that is, they were to exhibit creativity and act as strong role models. Being an innovative organization, according to SCG, also means establishing a creative work environment, including the processes of work, business models, and work practices.

As suggested above, SCG wants to be a sustainable business leader in ASEAN by 2015 and in order to achieve this, it has invested heavily in research and development, thus promoting itself as an innovative organization; its R\&D budget and personnel have consistently increased. In 2005, for example, there were 100 workers in research and the development budget for the year was about 40 million baht. The sales revenue from the resulting high value-added products was at 7,700 million baht (4 percent of total sales) during that same year. In 2012, SCG had nearly 1,000 staff members in the research and development department. This included around 70 $\mathrm{PhD}$ graduates and it had a research budget of more than 1,400 million baht per year at that time, again resulting in over 140,000 million baht of sales from high value-added products (34 percent of total sales).

\section{THREE STAGES OF GREEN IMPLEMENTATION}

\section{Stage One: Green Manufacturing}

SCG has chosen to use the best and most eco-friendly technologies as part of its green production processes. This is in keeping with SCG being a well-known leader in environmental management in Thailand. For example, SCG changed its cement production process-from a wet process, which uses water and thus expends a lot of energy, to a dry process, which reduces fuel use. SCG has also researched alternative energy sources to replace coal.

Another important moment regarding SCG's environmental performance was in 2006 when the world began to become aware that climate change was an environmental crisis. At that time, SCG released its "Zero Waste to Landfill" policy, which was to find a way to dispose of individual waste without having an impact on ecological systems. Following guidelines for sustainable environmental management, SCG applied the "3Rs" principle ("reduce, reuse/recycle, replenish") in order to improve the efficiency of its production processes and to minimize waste. In 2012, SCG sent only 0.3 percent of its hazardous waste and 3.6 percent of its non-hazardous waste to landfills.

\section{Stage Two: Sustainability Supply Chain}

The plan regarding a sustainable supply chain was begun in 2004 when SCG was the first company in Thailand to launch a "green procurement" policy, meaning that the company strove to purchase from companies that were environmentally friendly. In other words, SCG used products and services that were considered, and certified as such, 'green label" or that had passed SCG's green procurement standard. In this way, other organizations were encouraged to adopt eco-friendly practices. In the early stages, not many suppliers offered green products or services, but in recent years in Thailand, companies have adopted more environmentally-aware approaches. In 2012, there were 737 products and services on the green procurement list at a value of 3 billion baht. SCG has transferred the concept of sustainable development to its business partners, including producers, service providers, and distributors. They did this through what is known as the "Greening the Supply Chain" project which offers expertise, consultancy, incentive and encouragement regarding environmental management systems and safety measures. 


\section{Stage Three: Eco-Value Label and Eco-Value Products}

\section{Eco-Value Label}

In general, the actions of SCG concern the needs of consumers and society, this together with what is considered the "right thing to do." For instance, before the introduction of SCG's eco-value label, a study revealed that consumers tended to prefer eco-friendly products. This corresponded to SCG's vision of the importance of creating innovative, high value-added products and services, as well as environmental conservation, as mentioned above. This, in turn, led to the idea for SCG producing excellent quality products and services for the customer. The introduction of the SCG eco-value label was part of SCG's attempt to encourage consumers to use products and services that contributed to a better, safer environment.

In 2009, SCG issued the "SCG eco-value" product label by adopting ISO 14021: Environmental Labels and Declarations - Self-Declared Environment Claims standard. This was done in conjunction with the stakeholders' requirements and product lifecycle assessment. The word "eco" refers to both the economy and the ecology, while the word "value" refers to the value created for consumers, society, and the environment. SCG was the first organization in Thailand that introduced this label and it became a standard which certified that the SCG products and services that had these labels were produced using entirely environmental-friendly processes. In addition, the label ensured that the product would not harm the environment, possessed excellent quality, reduced the consumption of the natural resources, and helped to save the consumer money.

In 2013, Nelson conducted a survey with 2,000 consumers regarding various eco labels in Thailand. As shown in Figure 1, it was found that SCG's eco-value label was considered the most environmental-friendly logo (40\%), followed by the green label which was first established by the Thailand Business Council for Sustainable Development (33.5\%), and the No. 5 Energy Label, which was first established by the Electricity Generating Authority of Thailand (25.5\%). The SCG eco-value label was perceived as being environmental-friendly by $95 \%$ of the people, as innovation for a better life $(81 \%)$, as a product that one intended to buy $(81 \%)$, and as a product with a premium price $(66 \%)$.

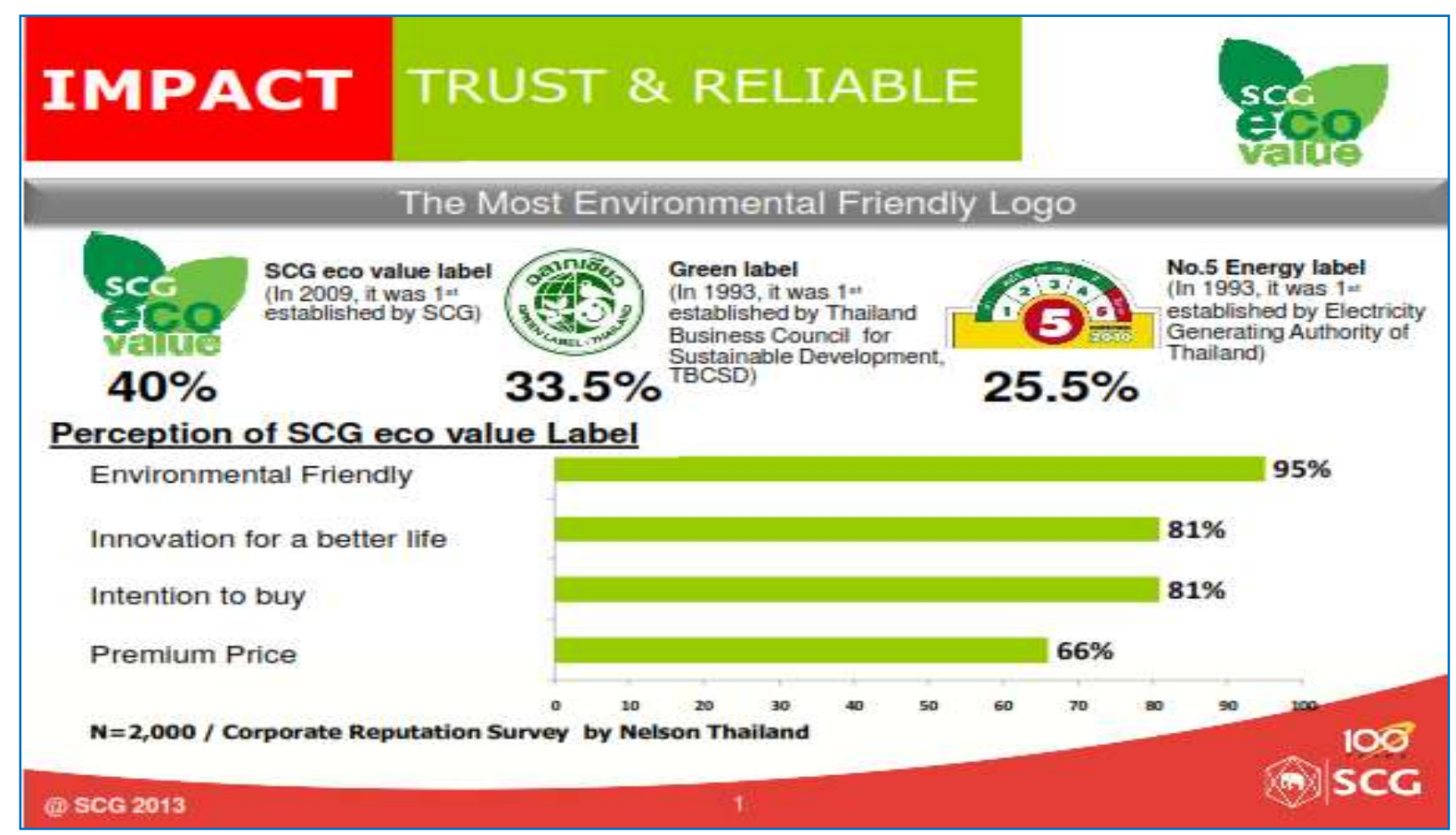

Figure 1: Perception of the SCG Eco Value Label 


\section{Eco-Value Products}

A wide range of eco-value products offered by SCG is currently available in the market; for example, products that use minimal natural resources such as Idea Green paper, which reduces the use of trees by 30 percent. Another innovative product is EL Green plastic pellets (used for plastic packaging); this is biodegradable under certain temperatures and moisture levels. At the same time, SCG Marine Cement is sea water resistant and the greenhouse gas emissions resulting from its production have been reduced by at least 350 kilograms per ton of cement. In addition to these products, SCG produces COTTO Hygenic Tiles, which are anti-bacterial, and SCG has the Logistics' Multimodal Management transportation system. This system effectively reduces greenhouse gas emissions through the improvement of its transport network and delivery systems.

In addition to the development of these eco-friendly products and services, SCG also has employed advertising campaigns that are designed to create awareness of SCG's eco-value label, thus making consumers cognizant of environmental issues as being of everyone's concern. Also, SCG thinks that purchasing eco-friendly products and services is one way to help save the world and maintain a good environment. Their campaigns have been conveyed through various media, and in 2009, the first TV commercial, entitled "Leaf", was launched to pass on the concept of eco products to consumers. The objectives were to build consumer consciousness regarding the use of eco-friendly products and services. The idea was that the consumer would be able to enjoy excellent quality products while contributing to a better environment at the same time. The success of this first effort in raising the concern of the public about the environment lead to a second TV commercial entitled "Concerning Number" in 2010 which highlighted the concept of the eco process or the environmental-friendly manufacturing process. The commercial was based on a report concerning sustainable development that compared the resource savings achieved from each of SCG's manufacturing processes. An example of this is as follows:

Paper production process: The use of eco fiber derived from recycled paper reduced the use of more than 2,500,000 trees which otherwise would have been cut down - twice the number of trees on Koh Samet Island.

In addition to this, SCG organized press conferences and participated in numerous seminars and exhibitions on the environment, both locally and internationally. They did this in order to provide knowledge to the interested public.

\section{STAKEHOLDERS' PARTICIPATIONS}

With diversified groups of stakeholders, such as customers, employees, suppliers, contractors, communities, shareholders, investors, creditors, government agencies, media, civil society, and academics and competitors, becoming integrated in terms of business conduct, SCG has been able to employ specific tools in its search for a good understanding of the stakeholders. Some examples of these tools include dialogues with stakeholders, stakeholder surveys, and joint meetings. SCG has been able to take into consideration people's complaints, suggestions and opinions and apply them to the improvement of its performance and its responses to each stakeholder group, thus resulting in sustainable growth based on participation and good corporate governance.

In 2012, a customer and stakeholder survey indicated over 90 percent satisfaction with SCG's conduct regarding sustainability development. The detailed survey results and comments will be used to improve future business plans.

\section{THE SUCCESS OF SCG}

As of 2013, SCG had 82 eco value-endorsed products and services and the revenue from these products comprised 26 percent of SCG's total sales. SCG forecasts that by 2015, the revenue from its eco-value innovations will reach one-third of its total sales. Additionally, 2013 will be the ninth year that the company has been ranked on the Dow Jones Sustainability Indexes (DJSI), which assesses the sustainable development performance of leading international companies, where SCG has been considered a leading company in sustainable development since 2004. In 2011 and 2012, SCG was ranked as a sector leader in the building materials and fixtures category. This recognition is a strong indication of SCG's success in sustainable development and also evidence that it has achieved world-class standards in this field. 


\section{CONCLUSION}

So far, SCG has been quite successful in implementing sustainable development. However, SCG can do more nationally and internationally in terms of spreading the concept of sustainable development to the parties involved and to the general public. This may include the instillation of environmental consciousness in the mind of the public, which will be one of the next big challenges that SCG might want to tackle.

\section{QUESTIONS}

1. Do you agree with the three stages of sustainability implementation? Why or why not?

2. Is the eco-value label invented by SCG trustworthy? Why or why not?

3. If you want to instill green consciousness in the mind of the general public, what strategies would you suggest?

4. If it were up to you, would you want to adopt the SCG model of being sustainable? Why or why not?

\section{ACKNOWLEDGEMENTS}

The author would like to thank Mr. Numpol Limprasert, sustainable development manager at Siam Cement group (SCG), for his kind cooperation and support during the data-collection process of this case study.

\section{AUTHOR INFORMATION}

Orose Leelakulthanit is an Associate Professor of Marketing in the Graduate School of Business, National Institute of Development Administration. She teaches marketing management, marketing research, and consumer behavior. Her research interests are mainly in the area of consumer behavior, quality of life, and green marketing. E-mail: orose@nida.ac.th

\section{REFERENCE}

1. Company website (2014). Retrieved June 9, 2014 from http://www.scg.co.th 


\section{NOTES}

